MAGDALENA JÓŹWIAK, WROCŁAW

\title{
IDEA NIEZAWINIONEGO CIERPIENIA W KOMENTARZU DO HISTORII HIOBA FILIPA PREZBITERA
}

„Patrz! Kładę dziś przed tobą życie i szczęście, śmierć i nieszczęście. Ja dziś nakazuję ci miłować Pana, Boga twego, i chodzić Jego drogami, zachowywać Jego polecenia, prawa i nakazy, abyś żył i mnożył się, a Pan, Bóg twój, będzie ci błogosławił w kraju, który idziesz posiąść. Ale jeśli swe serce odwrócisz, nie usłuchasz, zbłądzisz i będziesz oddawał pokłon cudzym bogom, służąc im - oświadczam wam dzisiaj, że na pewno zginiecie, niedługo zabawicie na ziemi, którą idziecie posiąść, po przejściu Jordanu" (Pwt 30, 15-18). Ten fragment z Księgi Powtórzonego Prawa przedstawia zasadę zwaną często „prawem dwóch dróg” i wiąże się z ideą odpłaty, która pojawia się niejednokrotnie na kartach Pisma Świętego. ${ }^{1}$ Przesłanie tego Bożego oświadczenia w pierwotnych formach religijności Izraela było proste: kto zachowa Boże przykazania, nakazy i zakazy, ten

1 Teoria ta ma różne wymiary i formy w samej Biblii, gdyż istnieje odpłata dla konkretnej osoby za jej czyny (por. Prz 11, 21.31; Prz 19, 17; Hi 1, 9; Hi 22, 2), jak i jest odpłata zbiorowa (por. Wj 20, 5; Wj 34, 7; Sdz 3, 7-8; 2Sm 24, 15-16; Syr 11, 20-28; Koh 9, 5). Raz jest to odpłata bezpośrednia i tymczasowa, innym razem odłożona do śmierci (Ps 37, 10; Ps 49, 17-18; Ps 73, 18-19; Hi 8, 8; Syr 11, 26-28). Z kolei autor Księgi Mądrości poucza o odpłacie eschatologicznej. Według jego sądu, po śmierci dusze sprawiedliwych są oddzielane od dusz złoczyńców: „A dusze sprawiedliwych są w ręku Boga i nie dosięgnie ich męka. Zdało się oczom głupich, że pomarli, zgon ich poczytano za nieszczęście i odejście od nas za unicestwienie, a oni trwają w pokoju. Choć nawet w ludzkim rozumieniu doznali kaźni, nadzieja ich pełna jest nieśmiertelności. Po nieznacznym skarceniu dostąpią dóbr wielkich, Bóg ich bowiem doświadczył i znalazł ich godnymi siebie. (...) A grzesznicy poniosą karę stosownie do swych zamysłów, bo wzgardzili sprawiedliwym i odstąpili od Pana" (Mdr 3, 1-5.10). 
osiągnie szczęście, którego wyrazem będzie Boże błogosławieństwo, kto zaś przekroczy Boże przepisy, tego spotka cierpienie i śmierć.

Sami Izraelici jednak szybko zauważyli, że prosty mechanizm wyrażony w ,prawie dwóch dróg” nie w pełni przystaje do rzeczywistości. Istnieją przecież ludzie, którym wiedzie się znakomicie, choć nie liczą się z przykazaniami Bożymi, oraz ci, którzy gorliwie zabiegają o zachowanie Bożego Prawa, a jednak spotykają ich nieszczęścia. $Z$ tego powodu poszukiwali rozwiązania tego dylematu, czego dowodem są choćby Ps 37 i Ps 73 oraz przede wszystkim Księga Hioba, która inspirowała wielu ludzi na przestrzeni wieków do refleksji nad problematyką niezawinionego cierpienia. ${ }^{2} \mathrm{U}$ autorów greckich i łacińskich w okresie antyku dostrzega się zainteresowanie tym zagadnieniem, którego świadectwem są egzegetyczne komentarze do Hioba. Przykładem egzegetycznej interpretacji Księgi Hioba jest również dzieło Filipa Prezbitera, które wyjaśnia literalnie i alegorycznie znaczenie tekstu biblijnego.

Artykuł ma na celu ukazanie, w jaki sposób Filip Prezbiter mierzy się z problematyką niezawinionego cierpienia $\mathrm{i}$ w jakim kierunku idą jego refleksje. Czy Hiob cierpi, gdyż dopuścił się grzechu? Czy może jest niewinny? A jeśli jest niewinny, to jaka jest przyczyna jego cierpienia? Podstawą źródłową jest Komentarz do historii Hioba autorstwa, żyjącego na przełomie IV/V w. Filipa Prezbitera, który uchodzi za ucznia św. Hieronima, co zaświadcza Gennadiusz w De viris illustribus $62 .{ }^{3}$ Ten komentarz nigdy jeszcze nie został przeanalizowany przez egzegetów biblijnych ani nie był przedmiotem pracy filologów, dlatego do dziś dysponujemy wyłącznie wydaniem

2 Na temat misterium cierpienia w Księdze Hioba zob. M. B. C r o o k, The cruel God: Job's search for the meaning of suffering, Boston 1959; A. J e p s e n, Das Buch Hiob und seine Deutung, Stuttgart 1963; J. L é vê qu e, Le sens de la souffrance d'après le livre de Job, Revue Théologique de Louvain 6/1975, s. 438-459; C. S t a n g e, Das Problem Hiobs und seine Lösung, Zeitschrift für systematische Theologie 32/1935, s. 342-355; W. B. W a r d, Out of whirlwind. Answers to the problem of suffering from the book of Job, Richmond 1958.

3 Philippus Presbyter, optimus auditor Hieronymi, commentatus in Job edidit sermone simplici librum, PL 58, 1096 B. 
z XVI w. Editio princeps $^{4}$ została wydrukowana w Bazylei w 1527 r. z kodeksu, który odnalazł w bibliotece w Fuldzie Johannes Sichard. Filip Prezbiter przez długie wieki był zesłany do otchłani autorów zapomnianych, a jego dzieło leżało zapomniane w bibliotece aż do odkrycia w 1991 r. przez M. P. Ciccarese ${ }^{5}$ najstarszego Filipowego kodeksu, pochodzącego z VIII w., a przekazanego pod nazwą Expositionum in Iob libri tres, który w incipicie przypisuje to dzieło Filipowi. Włoska badaczka odnalazła zaginiony kodeks, ja z kolei, podejmując badania nad komentarzem Filipa Prezbitera do Księgi Hioba z wydania bazylejskiego, ${ }^{6}$ poruszałam się po swoistej terra incognita, ponieważ nie istnieje w literaturze polskiej ani międzynarodowej żadna monografia poświęcona temu zagadnieniu.

4 J. S i c h a r d u s (wyd.), Philippi presbyteri viri longe eruditissimi in historiam Iob commentariorum libri tres, Basileae, per Adamum Petrum, mense Augusto, anno 1527.

5 Wyniki swojego odkrycia uczona przedstawiła w Una esegesi ,double face”. Introduzione all' „Expositio in Iob” del presbitero Filippo, Annali di storia dell' esegesi 9/1992, s. 483-492.

6 Por. M. Jóź w i a k, „,Komentarz do historii Hioba” Filipa Prezbitera, Wrocław 2013 (rozprawa doktorska napisana pod kierunkiem prof. G. Malinowskiego przy współudziale promotora pomocniczego dr. K. Morty, w Instytucie Studiów Klasycznych, Śródziemnomorskich i Orientalnych na Uniwersytecie Wrocławskim; obecnie w przygotowaniu do druku). Nadrzędnym celem dysertacji była ocena wartości egzegetycznej Komentarza do historii Hioba, który wyszedł spod pióra Filipa Prezbitera. Podjęto próbę udzielenia odpowiedzi na pytania, czy Filip jest oryginalny w egzegezie Księgi Hioba, czy może podaje interpretacje wcześniejszych komentatorów. Spośród zagadnień egzegetycznych opracowano obraz Hioba, obraz diabła, zaprezentowano stosunek ucznia św. Hieronima do Żydów, omówiono także obraz świętych, Chrystusa, Kościoła i heretyków. Drugim celem było ustalenie autorstwa omawianego dzieła, ponieważ kwestia autorstwa Filipowego komentarza jest dość problematyczna i skomplikowana na skutek panującego w świecie naukowym chaosu w sprawie pism, które wyszły rzeczywiście spod pióra Filipa Prezbitera. Trzecim celem dysertacji była ocena ucznia w świetle mistrza, czyli poszukiwanie podobieństw między św. Hieronimem a Filipem Prezbiterem. 
Filip Prezbiter In historiam Iob commentariorum libri tres dedykuje niejakiemu Nektariuszowi, ${ }^{7}$ którego najprawdopodobniej można identyfikować z Nektariuszem, biskupem Konstantynopola, żyjącym w IV w. Komentarz składa się z 3 ksiąg. W pierwszej księdze Filip omawia rozdziały 1-17, w drugiej 18-31, natomiast w trzeciej 32-42.

Filip interpretuje Księgę Hioba w kluczu dosłownym i alegorycznym, naśladując swego mistrza Hieronima, który w komentarzach biblijnych stosuje dwojaki rodzaj egzegezy. Komentator w alegorycznej interpretacji fragmentów z Księgi Hioba wielokrotnie przedkłada czytelnikowi niejednoznaczne wyjaśnienie, ponieważ nie raz podkreśla, że dany passus można interpretować na dwa sposoby, a mianowicie jako coś dobrego i jako coś złego (in bonam partem intelligimus; in malam partem intelligimus).

Fenomenem alegoryczności komentarza Filipa jest chrystologiczna interpretacja samego Hioba, który jest typem cierpiącego Chrystusa (,Sanctus Iob /.../ multa de Christo domino prophetavit, cuius etiam in se personam figuraliter gessit" ${ }^{\text {") }}$, obok prezentacji Hioba jako postaci historycznej. ${ }^{9}$ Uczeń św. Hieronima, choć sam nie wspomina o źródłach swego komentarza, jednak na bazie tekstu można wyprowadzić kilka argumentów na zależność Filipa od Orygenesa. ${ }^{10}$

Zupełnym novum w linii interpretacyjnej Księgi Hioba jest to, że Filip Prezbiter jako pierwszy spośród komentatorów sugeruje, iż trzej przyjaciele Hioba są figurą heretyków, a tajemniczy rozmówca Elihu jest obrazem pogan: „Sic ubi per totum hunc librum sanctum

7 „Adhortante te, immo potius compellente, Nectari pater beatissime, adgredior opus mihi valde arduum et difficile, quo de sancti Iob libro aliqua explanare praesumam” - „Wobec twej zachęty, a nawet raczej przymuszenia, najczcigodniejszy ojcze Nektariuszu, przystępuję do dzieła niesamowicie dla mnie żmudnego i trudnego, w którym zamierzam stopniowo poczynić wyjaśnienia o księdze świętego Hioba".

8 „Święty Hiob wiele prorokował o Chrystusie Panu, którego obraz także zawarł w sobie za sprawą alegorii"; P h i l i p p u s P r e s b y t e r, In historiam Iob commentariorum libri tres, Prolog (J. S i c h a rd u s-wyd.), s. 1.

9 Na temat portretu Hioba w Filipowym komentarzu zob. M. Jó ź w i a k, „Komentarz do historii Hioba” Filipa Prezbitera, s. 71-85.

10 Szerzej na ten temat zob. tamże, s. 39-41. 
Iob figuram Salvatoris habuisse perspicimus (...). Et in quibusdam locis amicos eius significari haereticos intelleximus, sicut etiam et illum Heliu gentialitatis habuisse imaginem disseruimus". ${ }^{11}$

Księga Hioba jest dziełem wielowarstwowym i niejednolitym, dlatego należy ją rozpatrywać pod różnymi kątami i na różnych płaszczyznach, jednak kwestia niezawinionego cierpienia wydaje się tematem przewodnim, ponieważ nie sposób mówić o Hiobie, nie dotykając tajemnicy jego cierpienia. Filip Prezbiter, komentując tę księgę biblijną, także podejmuje próbę poszukiwania odpowiedzi na pytanie o cierpienie niezasłużone. Starając się zmierzyć z tą problematyką, poddaje ocenie postawę przyjaciół Hioba oraz reakcję samego Hioba na cierpienie, które go dotknęło. Uczeń św. Hieronima stawia naprzeciw siebie tezy poszczególnych bohaterów, przyjmując, że Bóg ma udział w zjawisku cierpienia.

Przyjaciele Hioba kierują się klasyczną zasadą odpłaty, wedle której grzech pociąga za sobą cierpienie, zatem kto cierpi, musi być więc winny. Nie przyjmują do wiadomości żadnych zastrzeżeń i chcą swoje rozumowanie narzucić Hiobowi. Dla przykładu, wyjaśniając werset: „I wzmacniałeś drżące kolana” $(4,4)$ Filip sugeruje, że Elifaz, posługując się szyderstwem, poucza Hioba, iż gdyby postępował on sprawiedliwie, to nigdy nie spadłyby na niego tak wielkie nieszczęścia, które dobry i sprawiedliwy Bóg zesłał ku przestrodze dla innych: „Ista ergo in sanctum Iob cum irrisione dicuntur, habentia hunc sensum: Si haec quae dixi fecisses, nunquam ad haec tanta mala, ad exemplum mortalium, incidisses. Quia deum conditorem omnium rerum, bonum scimus et iustum". ${ }^{2}$

11 „Tak oto przez całą tę księgę dowodzimy, że święty Hiob mieścił w sobie figurę Zbawiciela (...). I zauważyliśmy, że w tych samych miejscach przyjaciele jego oznaczają heretyków, podobnie jak i wyjaśniliśmy, że ten Elihu zawarł w sobie obraz pogan"; P h i 1 i p p u s P r e s b y t e r, In historiam Iob commentariorum libri tres, 42, 11 ( J. S i c h a rd u s - wyd.), s. 209.

12 „Przeto te [słowa] są wypowiadane z szyderstwem wobec świętego Hioba, a mają taki sens: Gdybyś czynił to, o czym mówiłem, nigdy nie popadłbyś w te wielkie nieszczęścia jako przykład dla śmiertelników. Ponieważ wiemy, że Bóg [jest] dobrym i sprawiedliwym Stwórcą wszystkich rzeczy”; tamże, 4, 4; s. 12. 
Dalej Elifaz radzi Hiobowi, by nawrócił się do Boga i żałował za swe dawne przewiny, wówczas znowu będzie obfitował w cnoty i święte plany: „Potuit ergo Eliphaz, quasi consilium dans Iob, ita moraliter dicere: Si conversus ad dominum fueris, ita ut te tuorum operum antiquorum poeniteat, cordis tui virtutibus et sanctis cogitationibus velut seminibus abundabis". ${ }^{13}$

Filip komentując passus: „Czy Bóg obala sąd i Wszechmocny niszczy, co sprawiedliwe jest?” $(8,3)$ oświadcza, że Bildad, powołując się na Bożą sprawiedliwość, mówi, że Hiob cierpi to, na co sobie zasłużył: „Hoc dicit, quia iustitia dei pateris quae mereris, nisi reo, nequaquam inferri ista permitteret". ${ }^{14}$

W innym miejscu komentator podkreśla, że trzeci przyjaciel Hioba, Sofar, jest wzburzony jego zachowaniem, bo trzyma się on twierdzenia, że jest niewinny i uparcie oświadcza, iż znosi cierpienia bez słusznej przyczyny: „Eo quod haec mala poenarum innocentem te adferis sustinere, ideo inquit aestuo, et cogitatione conturbor, quia dicis te haec mala sine causa a Deo iusto iudice sustinere". ${ }^{15}$

Linijkę niżej Sofar gani Hioba, który jest oburzony zachowaniem swoich przyjaciół i wyjaśnia mu, że ma prawo udzielać odpowiedzi w imieniu Boga, który uchodzi za najsprawiedliwszego. Następnie przyjaciel Hioba podkreśla, że Bóg nie zsyła kary na nikogo, jeśli nie jest winny zła i licznych występków. ${ }^{16}$

13 „Mógł przeto Elifaz, jak gdyby udzielając rady Hiobowi, mówić zgodnie z sensem moralnym w ten sposób: Jeśli zwrócisz się do Pana tak dalece, że będziesz czuł żal z powodu twoich dawnych czynów, będziesz obfitował w cnoty twego serca i święte zamysły, jakby w potomstwo"; tamże, 5, 25; s. 19.

14 „To mówi, że według sprawiedliwości Boga cierpisz to, na co sobie zasłużyłeś, bo gdybyś nie [był] winny, wcale nie dopuściłby, aby te [nieszczęścia] zostały zadane"; tamże, 8, 3; s. 26.

15 „Wobec tego, że twierdzisz, iż ty będąc niewinnym cierpisz to zło nieszczęść, dlatego, rzekł, jestem wzburzony i zmieszany w myśli, ponieważ mówisz, że ty znosisz bez przyczyny te cierpienia [zesłane] przez Boga, sprawiedliwego sędziego"; tamże, 20, 1-2; s. 80.

16 „Auditam te quidem increpantem, ac redarguentem me, qui forte in doloribus positum obiurgare non debeam, sed spiritu quo sapiamus, continemur et regimur, ad hanc regulam nobis iustitiae et aequitatis dei respondit, quod non possit quisquam 
Hiob, odpowiadając przyjaciołom, twierdzi, że jest niewinny i przekonuje, iż nie uczynił nic wbrew przykazaniom Boga, co uczeń św. Hieronima niejednokrotnie podkreśla. Filip dowodzi, że tak jak zdrowy rozsądek nie pozwala, by można było spożyć coś nieposolonego, tak i Hiob nic nieposolonego, nic głupiego przeciwko Bogu, nic co nie zostało przyprawione solą wiary, nie uczynił: ,Quemadmodum ratio non sinit naturalis, ut bene sapere possit insulsus et nullo condimenti blandimento compositus cibus, ita ego nihil insulsum, nihil stultum contra dominum locutus sum, nihil quod non fidei sale conditum esset, operatus sum". ${ }^{17}$

Główny bohater Księgi Hioba tłumaczy przyjaciołom, że bał się nawet dopuścić do siebie najmniejszych grzechów, by za te nie spadła na niego kara Boża. Dalej żali się, że tak bardzo jest karany, jakby dopuścił się straszliwych występków: „Timebam etiam peccata minima perpetrare, ne pro eis dei in me ultio desaeviret et ecce nunc ita punior, tanquam scelera immania et execranda commiserim". ${ }^{8}$

Przyjaciele Hioba, głusi na jego argumentację, trzymają się swych idei, usiłując go przekonać o jego winie i zachęcają do wyznania grzechów i zawierzenia się miłosierdziu Boga, co autor zaświadcza w wielu miejscach. Za przykład niech posłuży komentarz do passusu z Hi 11, 16, w którym Filip wyjaśnia, że Sofar, posługując się alegorią przepływu wód, wskazuje na fakt, iż udręki Hioba będą mogły szybko od niego odstąpić, jeśli tylko zechce się poprawić i uzna

ab eo, nisi iniquitatum suarum merito condemnari” - „Mianowicie słyszę ciebie łającego i oskarżającego mnie, że ja właśnie nie powinienem ganić znajdującego się w cierpieniach, lecz za sprawą ducha, którym pojmujemy, jesteśmy ogarnięci i kierowani, stosownym jest, abyśmy my [odnosili się] do tej normy sprawiedliwości i bezstronności Boga, gdyż nikt nie może być przez niego przeto uznany winnym, tylko jedynie za swoje występki”; tamże, 20, 3 .

17 „Jak zdrowy rozsądek nie dopuszcza, że dobrze może smakować coś, co jest nie posolone i potrawa niezłożona z jakiejkolwiek nadającej przyjemny smak przyprawy, tak i ja nic nie posolonego, nic głupiego przeciw Panu nie powiedziałem, nic co nie zostało przyprawione solą wiary, nie uczyniłem"; tamże, 6, 6; s. 20.

18 „Zatem bałem się dopuścić [do siebie] najmniejszych grzechów, aby za te nie nadeszła na mnie kara Boga i oto teraz tak bardzo jestem karany, jakbym dopuścił się straszliwych i przeklętych występków"; tamże, 6, 16; s. 21. 
swą winę. Następnie uczeń św. Hieronima przekazuje, że niekiedy w Piśmie Świętym pod rzeczownikiem ,woda” kryją się udręki: „In transitu itaque aquarum Sophar hoc vult intelligi, quod tam cito possint descedere ab eo dolores, si tamen Iob se emendare voluerit, quemadmodum aquae intra momentum ad loca alia elabuntur. Sciamus tamen tribulationes in scripturis aliquoties aquarum nomine nuncupari, ut est illud in psalmo: «Misit de summo, et accepit me, et adsumpsit me de multitudine aquarum»". ${ }^{19}$

I taki schemat przejawia się przez cały komentarz, a mianowicie przyjaciele oskarżają Hioba o dopuszczenie się grzechów, tym tłumaczą nieszczęścia, które go spotkały. Wedle zasady: winny musi ponieść karę. Z kolei Hiob trwa uparcie i pewnie przy swej niewinności, choć nie rozumie, dlaczego on, będąc człowiekiem sprawiedliwym, doświadcza cierpienia. Zarysowawszy sytuację, oddajmy głos Filipowi Prezbiterowi i zobaczmy, jak on sobie poradził z problematyką niezasłużonego cierpienia.

Trzeba podkreślić, że Filip jasno i wyraźnie w swym komentarzu definiuje, jaka była przyczyna sporu Hioba z jego przyjaciółmi. A mianowicie ów spór polegał na tym, że Hiob uważał się za sprawiedliwego, przyjaciele jego zaś twierdzili, że jest grzesznikiem, gdyż inaczej nie cierpiałby tych wszystkich nieszczęść: „Tota autem altercatio sancti Iob et eius amicorum huiusmodi est. Hic dicit innocentem se poenas pati criminosorum, illi dicunt non posse pati poenas, nisi peccati reum. Et his maxime disputationibus totus liber iste contexitur".$^{20}$

19 „I tak [przez alegorię] przepływu wód, Sofar chce wskazać na to, że wówczas udręki [Hioba] będą mogły szybko od niego odstąpić, jeśli jednak Hiob zechce się poprawić, tak jak wody, [które] w ciągu chwili rozlewają się do innych miejsc. Przecież wiemy, że w Piśmie Świętym uciski niejednokrotnie ukrywają się pod słowem «wody», gdyż jest to w Psalmie: «Posłał z wysoka i chwycił mnie i wydobył mnie z mnogości wód» (Ps 17, 17)”; tamże, 11, 16; s. 39.

${ }^{20}$ „A mianowicie cały spór świętego Hioba z jego przyjaciółmi [polegał] na tym. Ten mówi, że on [będąc] niewinnym cierpi kary [właściwe dla] przestępców, tamci [zaś] twierdzą, że nie może cierpieć kar, jeśli nie jest winny grzechu. I ta cała księga w dużym stopniu jest przeplatana takimi dysputami”; tamże, 9, 23; s. 33. 
Uczeń św. Hieronima ewidentnie staje po stronie Hioba, broni go, zaświadczając i podkreślając niejednokrotnie, że był on człowiekiem prawym, uczciwym, sprawiedliwym, wiernym Bogu we wszystkim. Na wielu kartach swego komentarza świadczy o niewinności Hioba. Z kolei przyjaciół Hioba nazywa jego wrogami, kłamcami, obłudnikami, bluźniercami. Filip przekonuje, że oni sami potrzebują nawrócenia i weryfikacji swego postępowania. Powinni oni okazać skruchę na skutek goryczy swych mów, którymi dręczą Hioba.

Zatem jeśli Hiob jest niewinny, a przyjaciele jego nie mają racji, jaka jest przyczyna Hiobowego cierpienia? Ten problem Filip rozwiązuje na kilku płaszczyznach.

Po pierwsze, komentator uznaje, że cierpienie Hioba jest swoistą tajemnicą, której człowiek nie jest w stanie pojąć, ani racjonalnie wyjaśnić. Tylko dobry i sprawiedliwy Bóg wie, jaki jest sens Hiobowego cierpienia, zwłaszcza że na początku księgi wydał o Hiobie dobre świadectwo: ${ }^{21}$ „Obstupescite et miramini quod sit istud secretum, ut deus bonus et iustus erga me taliter operetur, praesertim cum eius testimonium de me bonum habeam". ${ }^{22}$

Po drugie, uczeń św. Hieronima wyjaśnia, że nieszczęścia, które dotknęły sprawiedliwego Hioba, są próbą zesłaną na niego przez Boga, o czym mówi w Hi 16, 19. Wedle przekonania Filip, udręki słusznie są zsyłane przez Boga na bezbożników jako kara, na sprawiedliwych zaś jako próba: „Hoc autem loco clamorem positum, ipsam sanctitatem eius contra poenas illius reclamantem, quae ab iniquis merito inferuntur, iustis ad probationem, non absurde sentiamus". 23

21 Por. Hi $1,1$.

22 „Bądźcie zdumieni i dziwcie się, gdyż jest to tajemnicą, iż dobry i sprawiedliwy Bóg postępuje wobec mnie w taki sposób, zwłaszcza że posiadam jego dobre świadectwo o mnie"; P h i l i p p u s P r e s b y t e r, In historiam Iob commentariorum libri tres 21, 5 (J. S i c h a rd u s - wyd.), s. 85.

${ }^{23}$ „Zaiste słusznie odczytujemy, że w tym miejscu pojawiający się krzyk jest protestem tej jego świętości wobec jego udręk, które słusznie są zsyłane na bezbożników, na sprawiedliwych zaś jako próba"; tamże, 16, 19; s. 69. 
Filip, analizując wyżej poddany passus, wyjaśnia, że słowo „krzyk” można interpretować trojako. ${ }^{24}$ A mianowicie, niekiedy krzyk wskazuje na uczucie duszy wołającej do Pana, gdzie za przykład komentator stawia Dawida. ${ }^{25}$ Innym razem krzyk może być zestawiany z nieprawością, co można zauważyć u proroka Izajasza. ${ }^{26}$ I na końcu Filip wyjaśnia, że sam Pan nawiązał do krzyku, wzywając Jonasza, by udał się z prorockim upomnieniem do Niniwy. ${ }^{27}$

Po trzecie, autor komentarza podkreśla, że wyroki Boga są niezbadane, niepojęte i zakryte przed człowiekiem. Plany Boskie są nieogarnioną tajemnicą, którym człowiek jest zupełnie poddany, o czym Filip zaświadcza w Hi 23, 14. Bóg, jeśli zechce, to będzie mógł przybić Hioba jeszcze większymi cierpieniami, ponieważ wszystko jest mu podległe: „Cum me quibus voluerit tormentis adfecerit et alia adhuc quanta voluerit mihi infligere poterit, quoniam omnia praesto sunt ei quaecunque voluerit". ${ }^{28}$

24 „Aliquando tamen clamor in scripturis, sicut et hoc loco, intus ad dominum orantis animi demonstratur affectus, ut et sanctus: David ait. Domine exaudi orationem meam, et clamor meus ad te perveniat. Aliquando etiam clamor et iniquitas dicitur, ut Esaias ait: Ex sermonibus domini culpantis vineam suam: Exspectavi ut faceret iudicium, fecit autem iniquitatem, et non iustitiam, sed clamorem. De quo clamore ipse dominus loquitur ad Ionam prophetam: Surge et vade in Niniven civitatem magnam, et praedica in ea, quia ascendit clamor malitiae eius ad me" „Jednak niekiedy krzyk w Piśmie Świętym, tak jak i w tym miejscu, wskazuje na uczucie duszy wołającej z wnętrza do Pana, gdyż i święty Dawid mówi: „Panie, wysłuchaj modlitwę moją i krzyk mój niech do ciebie dotrze. Niekiedy także krzyk wiąże się z nieprawością, ponieważ Izajasz mówi, gdy Pan łaja winnicę swoją: «Oczekiwałem, aby wykonał sąd, uczynił zaś nieprawość, a nie sprawiedliwość, lecz krzyk». Sam Pan wspomina o tym krzyku, [zwracając się] do Proroka Jonasza: «Wstań i idź do Niniwy, miasta wielkiego i głoś w nim, że krzyk niegodziwości jego dotarł do mnie»"; tamże, 16, 19; s. 69.

25 Por. Ps 101, 2.

26 Por. Iz 5, 7.

27 Por. Jon 1, 2.

28 „Skoro zechciał, to już mnie dotknął tymi cierpieniami i będzie mógł mnie przybić jeszcze innymi tak samo wielkimi, ponieważ wszystko jest na wyciągnięcie jego ręki i cokolwiek [tylko] zechce"; P h i li p pus Pres by ter, In historiam Iob commentariorum libri tres 23, 14 (J. S i c h a r d u s - wyd.), s. 93. 
Po czwarte, Filipowe refleksje dotyczące niezasłużonego cierpienia modyfikują zasadę odpłaty, która, wedle przekonania ucznia św. Hieronima, nastąpi po śmierci. Filip, komentując passus z Hi 21, 27, zaznacza, że na tym świecie jedno jest położenie grzesznika i człowieka świętego. Dopiero po śmierci obaj zostaną poddani rozróżnieniu, gdyż sprawiedliwi powstaną do nagrody, nieprawi zaś otrzymają karę: „Cum ergo rectedefiniam (sic!), inquit, quod et vos verum esse perspicitis, quia una sit in hoc seculo sancto et peccatori moriendi conditio, qui tamen meritis postea disiungentur, ut ad praemium invi tentur iusti, ad supplicum rapiantur iniusti”. ${ }^{29}$

W przekonaniu Filipa Prezbitera cierpienie człowieka sprawiedliwego jest zawsze tajemnicą oraz próbą zesłaną przez Boga w celu weryfikacji wiary. W obecnym porządku rzeczywistości obok tego, co dobre, istnieje również chaos zła, uderzający w swoje ofiary w sposób nieprzewidywalny, ale nie jest on w stanie zniweczyć niepojętego planu Boga, zapisanego i realizowanego w stworzeniu. To, co odkrywa Hiob, to tajemnica Boga, w rękach którego znajduje się wszystko i nawet jeśli się wydaje, że Bóg nie panuje nad siłami zła, to są tylko pozory. Czy jednak siły zła muszą zostać wyeliminowane od razu? Gdy człowiek staje wobec zła fizycznego, choroby, cierpienia, śmierci, to czy zawsze trzeba dopatrywać się w cierpiącym kary za jego grzechy? Filip na obydwa pytania odpowiada przecząco, chwaląc postawę Hioba, który do końca był wierny Bogu, a w trudnych chwilach cierpienia, nigdy ostatecznie w niego nie zwątpił, mimo wielu pytań i wątpliwości.

Magdalena JÓŹWIAK

${ }^{29}$ „Otóż właśnie słusznie twierdzę, rzekł, że i wy pojmujecie, iż prawdą jest, że na tym świecie jedno jest położenie dla świętego i grzesznika mającego umrzeć, oni jednak później za zasługi są poddawani rozróżnieniu, gdyż sprawiedliwi zmieniają się do nagrody, niesprawiedliwi zaś są pochwyceni do kary"; tamże, 21, 27; s. 87. 